\title{
Industrial Tests of Programmed Equipment Complex "Granics" Performed in The Facilities of Erdenet Mining Corporation, Mongolia
}

\author{
V. Krouglov \\ GOU VPO "The Ural Federal University named after the first President of Russia B.N. Eltsyn", \\ Ekaterinburg, Russia (620002, Ekaterinburg, ul. Mira, 19)
}

\begin{abstract}
Described herein is a programmed equipment complex "Granics" designed to determine the grain composition of loose material particles on the example of estimating geometrical sizes of iron ore lumps. Results of operating algorithm for processing of images of iron ore particles are illustrated. Results of full-scale testing of the complex at the mining and processing works are analyzed.
\end{abstract}

Keywords-technical vision system; grain size analysis; digital processing of images; crushed material particles; nominal size; size under control

\section{INTRODUCTION}

It is always very important for the mining and processing works that the use of material and energy resources can be reduced. One of the tasks is achievement of stable grain size of crushed ore within the specified process parameters throughout all the stages of its processing. To solve this problem it is necessary in particular to develop new metering devices featuring multifunctionality, high accuracy and high speed of response. Most fully complying with these requirements are devices based on the technical vision system. These systems have such a merit as contactless measurement of parameters to be determined in the objects under study. Use of technical vision systems in mining industry allows to carry out visual separation of ores, microscopic estimation of minerals, optical measurement of various objects sizes and solve other tasks. Great interest to such systems is confirmed by a considerable number of publications devoted to their development and implementation [1-7]. The present article represents results of industrial tests of programmed equipment complex "Granics" designed to determine distribution of geometrical sizes of crushed, palletized or granulated flowing material.

\section{BASIC PART}

Industrial tests of "Granics" serviceability were performed in the facilities of crushing and handling division of Erdenet Mining Corporation, Mongolia, and lasted from 19.02.2014 till 12.06.2014. In the course of tests the following was checked: the accuracy of the complex software estimation of the crushed ore grain size and the complex hardware operating reliability. Erdenet Mining Corporation reduces ore in its crushing and handling division in several stages after which the crushed ore arrives at collecting conveyor No. 18 . Therefore for quality control of the whole crushing and handling division work it was decided to place an image reader of the "Granics" complex above this conveyor. General view of the image reader above conveyor No. 18 is given in Figure. 1. The complex was commissioned on 08.02.2014 after fulfillment of all start-up and setup jobs.

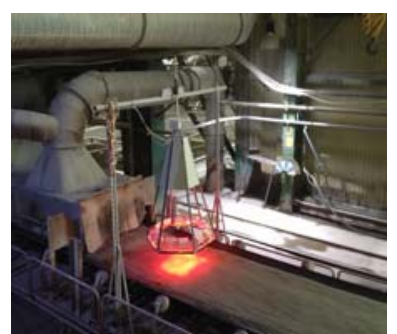

FIGURE I. GENERAL VIEW OF IMAGE READER ABOVE CONVEYOR NO. 18 .

Example of "Granics" software functioning in estimation of crushed ore size on conveyor No. 18 is given in Figure. 2.

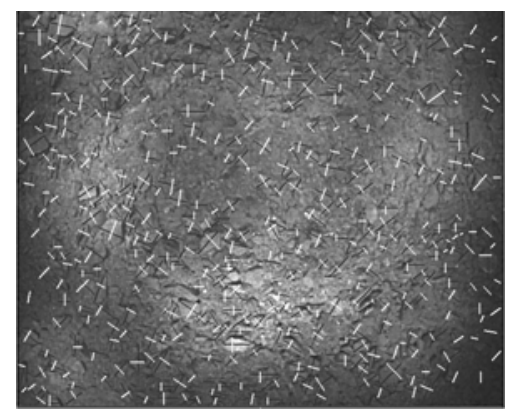

FIGURE II. RESULT OF OPERATING ALGORITHM FOR ESTIMATION OF CRUSHED ORE SIZE.

In digital processing of video images frame segmentation into patches is performed followed by classification whether it is stone or sand. Thereupon the following parameters for every crushed ore lump are calculated: lump area, lump principal axis and maximum size determined in the direction square to the principal axis of the object. The last size will correspond to the screen analysis size and thus it will be called the screen size of the crushed ore lump. Lines corresponding to the maximum width of the ore particle image area are painted white in Figure. 2. Painted black in Figure. 2 are principal axes of ore particles [8]. Two specified parameters of crushed ore, namely nominal ore size and content of " $+15 \mathrm{~mm}$ " size are characteristic of the crushing and handling division work effectiveness. Taken for nominal or conventional size of 
crushed ore is mesh size of the screen whose residue is 5 per cent. Figure. 3 shows "Granics" software fundamental mode reflecting results of the crushing and handling division work for the period between 08:00 and 20:00 as of 01.05.2014 taken from the complex archive.

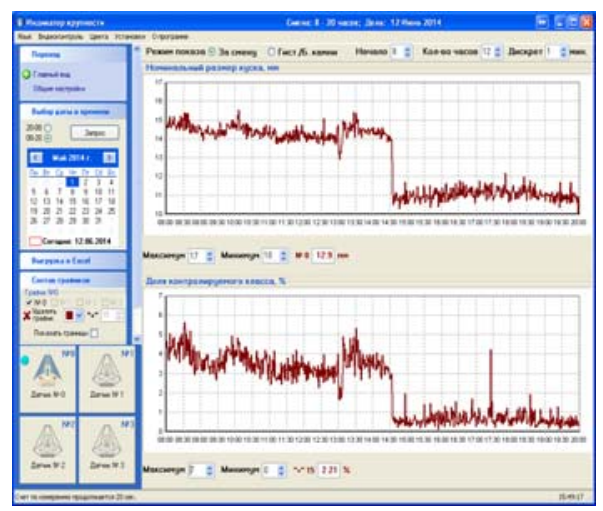

FIGURE III. WORKING SHIFT FROM 08:00 TILL 20:00 ON 01.05.2014.

For evaluation of the "Granics" complex performance a certain industrial testing program was approved and beginning from 26th February of 2014 the Central Test Laboratory (CTL) of the works made ore sampling after fine crushing from conveyor No. 18 to determine the condition and nominal size with concurrent registration of the same parameters of crushed ore from the software readings. For grain size of the ore entering the main building of Erdenet Mining Corporation refer to Tables 1 and 2 .

TABLE I .GRAIN SIZE OF ORE ACCORDING TO CTL REPORTS.

\begin{tabular}{|c|c|c|c|c|c|c|c|}
\hline $\begin{array}{c}\text { Size, } \\
\text { mm }\end{array}$ & $\begin{array}{c}\text { 2614 } \\
\text { 2014 }\end{array}$ & $\begin{array}{c}\mathbf{2 0 1 4} .03 \\
\mathbf{2 0 1 4}\end{array}$ & $\begin{array}{c}\mathbf{0 5 . 0 3} \\
\mathbf{2 0 1 4}\end{array}$ & $\begin{array}{c}\mathbf{0 6 . 0 3} \\
\mathbf{2 0 1 4}\end{array}$ & $\begin{array}{c}\mathbf{1 0 . 0 3 . 2} \\
\mathbf{0 1 4}\end{array}$ & $\begin{array}{c}\mathbf{1 2 . 0 3} . \\
\mathbf{2 0 1 4}\end{array}$ & $\begin{array}{c}\mathbf{1 9 . 0 3} \\
\mathbf{2 0 1 4}\end{array}$ \\
\hline 20 & 0.09 & 0.08 & 0.05 & 0.14 & 0.08 & 0.06 & 0.13 \\
\hline 18 & 0.46 & 0.61 & 0.53 & 0.73 & 0.48 & 0.50 & 0.52 \\
\hline 15 & 2.32 & 2.46 & 2.45 & 3.76 & 2.80 & 2.74 & 2.37 \\
\hline 12.5 & 11.48 & 11.72 & 11.46 & 14.02 & 13.38 & 10.85 & 12.08 \\
\hline 6.3 & 32.91 & 33.67 & 35.47 & 32.94 & 35.02 & 31.43 & 36.66 \\
\hline-6.3 & 52.74 & 51.46 & 50.04 & 48.41 & 48.24 & 54.42 & 48.24 \\
\hline $\begin{array}{c}\text { TOT } \\
\text { AL }\end{array}$ & 100.00 & 100.00 & 100.00 & 100.00 & 100.00 & 100.00 & 100.00 \\
\hline
\end{tabular}

TABLE II .GRAIN SIZE OF ORE ACCORDING TO "GRANICS" SYSTEM READINGS.

\begin{tabular}{|c|c|c|c|c|c|c|c|}
\hline Size, mm & $\begin{array}{c}\text { 26.02. } \\
\text { 2014 }\end{array}$ & $\begin{array}{c}\text { 03.03. } \\
\text { 2014 }\end{array}$ & $\begin{array}{c}\text { 2014. } \\
\text { 2014 }\end{array}$ & $\begin{array}{c}\mathbf{2 0 1 0 3} \\
\mathbf{2 0 1 4}\end{array}$ & $\begin{array}{c}\mathbf{1 0 . 0 3} \\
\mathbf{2 0 1 4}\end{array}$ & $\begin{array}{c}\mathbf{1 2 . 0 3} \\
\mathbf{2 0 1 4}\end{array}$ & $\begin{array}{c}\mathbf{1 9 . 0 3 .} \\
\mathbf{2 0 1 4}\end{array}$ \\
\hline 20 & 0.47 & 0.62 & 0.46 & 0.44 & 0.67 & 0.43 & 0.66 \\
\hline 15 & 2.34 & 3.13 & 2.66 & 2.17 & 2.93 & 2.15 & 2.95 \\
\hline 12 & 7.82 & 9.65 & 8.40 & 7.39 & 8.79 & 7.30 & 8.76 \\
\hline 10 & 9.73 & 11.32 & 10.49 & 9.37 & 10.34 & 9.44 & 10.34 \\
\hline 6 & 20.16 & 22.49 & 21.29 & 19.05 & 19.80 & 19.60 & 20.87 \\
\hline-6 & 59.48 & 52.79 & 56.70 & 61.58 & 57.47 & 61.08 & 56.42 \\
\hline TOTAL & 100.00 & 100.00 & 100.00 & 100.00 & 100.00 & 100.00 & 100.00 \\
\hline
\end{tabular}

For the purpose of making a comparative analysis of the data obtained Table 3 shows results of determining nominal size of crushed ore and content of " $+15 \mathrm{~mm}$ " size in it.
TABLE III .RESULTS OF DETERMINING NOMINAL SIZE OF CRUSHED ORE AND CONTENT OF “+15 MM” SIZE IN IT.

\begin{tabular}{|c|c|c|c|c|}
\hline \multirow{2}{*}{ Date } & \multicolumn{2}{|c|}{ Nominal size, mm } & \multicolumn{2}{c|}{$\begin{array}{c}\text { Content of "+15 mm" } \\
\text { size }\end{array}$} \\
\cline { 2 - 5 } & $\begin{array}{c}\text { Data from } \\
\text { CTL }\end{array}$ & $\begin{array}{c}\text { "Granics" } \\
\text { software } \\
\text { readings }\end{array}$ & $\begin{array}{c}\text { Data from } \\
\text { CTL }\end{array}$ & $\begin{array}{c}\text { "Granics" } \\
\text { software } \\
\text { readings }\end{array}$ \\
\hline $\begin{array}{c}26.02 .20 \\
14\end{array}$ & 14.30 & 13.81 & 2.87 & 2.81 \\
\hline $\begin{array}{c}03.03 .20 \\
14\end{array}$ & 14.40 & 14.37 & 3.15 & 3.75 \\
\hline $\begin{array}{c}05.03 .20 \\
14\end{array}$ & 14.40 & 14.03 & 3.03 & 3.12 \\
\hline $\begin{array}{c}06.03 .20 \\
14\end{array}$ & 14.80 & 13.71 & 4.63 & 2.61 \\
\hline $\begin{array}{c}10.03 .20 \\
14\end{array}$ & 14.50 & 14.26 & 3.36 & 3.60 \\
\hline $\begin{array}{c}12.03 .20 \\
14\end{array}$ & 14.40 & 13.71 & 3.30 & 2.58 \\
\hline $\begin{array}{c}19.03 .20 \\
14\end{array}$ & 14.40 & 14.26 & 3.02 & 3.61 \\
\hline $\begin{array}{c}\text { Mean } \\
\text { value }\end{array}$ & 14.46 & 14.02 & 3.34 & 3.15 \\
\hline $\begin{array}{c}\text { Relative } \\
\text { error }\end{array}$ & \multicolumn{2}{|c|}{$3.01 \%$} & \multicolumn{2}{|c|}{5} \\
\hline
\end{tabular}

There are quite different principles for evaluation of one and the same manufacturing process used by the "Granics" complex and by the CTL. Though the above results show that relative error for nominal size of crushed ore determined by the "Granics" complex is $3.01 \%$ only as compared with the CTL results while in evaluation of " $+15 \mathrm{~mm}$ " size the same error is $5.48 \%$. Besides, the industrial tests which were performed show that the complex clearly traces the trend of the grain size distribution in crushed material. Let us analyse data received during the shift from 08:00 till 20:00 on 01.05.2014 (Figure. 3). Beginning from 08:00 till 14:30 nominal size is $\sim 14.5 \mathrm{~mm}$., while beginning from $14: 30$ this factor goes down to $\sim 11 \mathrm{~mm}$. So, during 6 hours and 30 minutes the process ran yielding products with increased nominal size which may result in greater power consumption in the course of ore grinding in the mill.

For estimation of the "Granics" complex response experiments were carried out in the crushing and handling division with all crushers switched off but one operating under different loads. Table 4 shows results of experiments obtained on 11.04.2014 and 18.04.2014.

TABLE IV .RESULTS OF DETERMINING NOMINAL SIZE AND “+15 MM” SIZE CONTENT IN CRUSHED ORE.

\begin{tabular}{|c|c|c|c|c|}
\hline Date & \multicolumn{2}{|c|}{11.04 .2014} & \multicolumn{2}{|c|}{18.04 .2014} \\
\hline Crusher & \multicolumn{2}{|c|}{ KMD No. 16A } & \multicolumn{2}{|c|}{ KMD No. 15} \\
\hline Load, $\mathbf{t} / \mathbf{h}$ & 440 & 465 & 440 & 465 \\
\hline & $13: 31 \div 1$ & $13: 35 \div 1$ & $13: 37 \div 1$ & $13: 43 \div 1$ \\
\hline Time interval & $3: 35$ & $3: 42$ & $3: 43$ & $3: 54$ \\
\hline $\begin{array}{c}\text { Content of "+15 mm" } \\
\text { size determined by } \\
\text { CTL, \% }\end{array}$ & 6.23 & 3.826 .30 & 3.82 & 3.70 \\
\hline $\begin{array}{l}\text { Content of "+15 mm" } \\
\text { size from "Granics" } \\
\text { software, \% }\end{array}$ & 6.09 & 5.52 & 5.07 & 3.92 \\
\hline $\begin{array}{c}\text { Nominal size } \\
\text { determined by CTL, MM }\end{array}$ & 15.2 & \begin{tabular}{c|c}
14. & 15.3 \\
6 & 15.3
\end{tabular} & 14.7 & 14.7 \\
\hline $\begin{array}{c}\text { Nominal size from } \\
\text { "Granics" software, } \text { Mм }\end{array}$ & 15.71 & 15.45 & 15.35 & 14.76 \\
\hline
\end{tabular}


These results allow drawing the following conclusions:

- variability of the " $+15 \mathrm{~mm}$ " size factor under control made up in the above experiments $0.76 \%$ in absolute figures as reported by the CTL while according to the "Granics" software readings it made up $0.86 \%$;

- variability of the "nominal size" factor made up $0.19 \mathrm{~mm}$ in absolute figures as reported by the CTL and the "Granics" software showed $0.43 \mathrm{~mm}$.

\section{CONCLUSION}

Thus, despite the fact that the "Granics" complex determines the values of parameters under control on the surface of the first layer of ore only the variability of these parameters under conditions of dynamically changing operating modes of crushers shown by the "Granics" complex is higher than that reported by the CTL. Considering the fact that the CTL reports become available for the attending personnel with great delays a system similar to the "Granics" complex is the only possible means of on-line control and monitoring of the materials crushing process. Timely warning of the crushing and handling division personnel about worsened product quality ratings is the main advantage of using such systems.

\section{REFERENCES}

[1] Junker B. Measurement of bubble and pellet size distributions: past and current image analysis technology. Bioprocess Biosyst Eng. 185-206 (2006).

[2] Mukherjee D., Potapovich Y., Levner I., Zhang H. Ore image segmentation by learning image and shape features. Pattern Recognition Letters. 30 615-622 (2009).

[3] Al-Thyabat S., Miles N.J., Koh T.S.. Estimation of the size distribution of particles moving on a conveyor belt. Minerals Engineering. 20 72-83 (2007).

[4] Tessier J., Duchesne C., Bartolacci G. A machine vision approach to online estimation of run-of-mine ore composition on conveyor belts. Minerals Engineering. 20 1129-1144 (2007)

[5] Koh T.K., Miles N.J., Morgan S.P., Hayes-Gill B.R. Improving particle size measurement using multi-flash imaging. Minerals Engineering. 22 537-543 (2009)

[6] Jemwa G.T., Aldrich C. Estimating size fraction categories of coal particles on conveyor belts using image texture modeling methods, Expert Systems with Applications. 39 7947-7960 (2012)

[7] Sonka M., Hlavac V., Boyle R. Image processing, analysis, and machine vision Brooks/Cole Publishing Company. 1999770.

[8] Krouglov V., Geometrical dimensions definition system for bulk particles, 8th Open German-Russian Workshop "Pattern Recognition and Image Understanding". 165-167 (2011). 